\title{
The Impact of Internal Governance on Bearing the Risk of City Commercial Banks
}

\author{
Yanhui Hu \\ Jinan University, Guangzhou, China \\ Email: 15521332381@163.com
}

Received 19 January 2016; accepted 24 February 2016; published 29 February 2016

Copyright (C) 2016 by author and Scientific Research Publishing Inc.

This work is licensed under the Creative Commons Attribution International License (CC BY). http://creativecommons.org/licenses/by/4.0/

\begin{abstract}
Improving the internal governance is the key factor to promote the development of banking stability, especially for the banks which are just stepping on the right way. This article chose 23 city commercial banks, which had more than 50 billion assets, as the object of study and got the data of them through reading their annual reports from 2008 to 2014 for the empirical study. From the research, we found out that there was no significant relationship between the nature of the bank's largest shareholder and the banking risk, and the ownership concentration, board size, salary incentive and regional GDP had an opposite relationship with the banking risk, the independent director proportion and banking risk were positively related.
\end{abstract}

\section{Keywords}

Internal Governance, City Commercial Banks, Banking Risk

\section{Introduction}

The predecessor of the city commercial banks in China are urban credit cooperatives which were set up in the 1980s, it is an important and special group of China's banking sector. It was set up by the original purpose to solve the problem of small and medium-sized enterprise financing difficulties, to provide financial support for local economic development; because this kind of market positioning, city commercial banks in our country suffered a more severe shock than large commercial banks in financial deepening reform. As a new product for the nation to clean up the credit cooperatives and dissolve the risk of local products, city commercial banks, on the one hand, replace bad assets to jilt to take off the old baggage by restructuring mergers and acquisitions, and on the other hand, strengthen the construction of internal governance and risk management construction by actively improving internal management to enhance their overall competitiveness. As of November 2013, there were as many as 145 city commercial banks, and in the third quarter of 2014, the total assets accounted for ten 
percent of the entire banking industry, which become an integral part of the banking sector.

Even though the city commercial bank smoothly passed the difficult start (1995-2000), efforts to adjust (2000-2004), rapid development stage (2004-), now it is in a critical period of transition, whether it can meet the demand of the market, seize the market opportunity or not is a primary issue in the future, and the conditions those related to bank itself are also important to keep up with the pace of the market. Especially in 2015, the "new normal" has become China's current macroeconomic situation, the new normal and new features also cause financial ecological new change. The development model of commercial banks, risk characteristics and business structure show new evolution, and the external environment will also give a city commercial bank the fundamental impact on the development of strategic direction [1]. But now, the development of city commercial bank is not very well as the banking industry competition is intense. The assets, reputation and credibility affect the development of the banks to a great extent, thus most of the businesses are forced to face problems such as unclear orientation of the market.

But for the bank's internal governance issues, many scholars have made a lot of research results about the public company, they found the bank's internal governance had great influences on the risk exposure levels and business performance, however, due to the relatively small size of the city commercial banks, data access is difficult, so the relevant study of city business is relatively rare.

Bank governance relative to the general enterprise's corporate governance has its special way. General corporate governance usually only involves the relationship between the shareholders, creditors and executives, but because of government intervention and supervision, banks have to consider the government. So on the basis of predecessors' research, this article is divided into three parts: namely the ownership structure, board size and executive compensation incentive. In the study of equity structure, relative to the listed banks, one special factor of city commercial bank is the nature of the largest shareholder. As the ministry of finance is involved in the business of city commercial bank's early development, the existence of the government and the implicit guarantee will to some extent increase the probability of bank risk. In 2015, it was emphasized in the two sessions that the government would allow some bank failures; the small city commercial banks would suffer greater risk than large commercial bank. Thus, in this article, we study the city commercial bank's risk bearing through the empirical analysis from the perspective of internal governance, hoping to draw the specific relationship between internal governance and risk bearing, and put forward some policy suggestions for reference at the same time.

\section{Literature Review}

Since the 1980s, the frequent financial crisis has affected a lot of banks; the academic studies have found that it's largely due to the inadequate internal governance. This problem is mainly composed of the principal-agent problem between shareholders and management, shareholders and creditors. Bank risk bearing mainly depends on the manager's intention, the engaged in risk behavior motive and decision determines how much of risk the Banks will bear, and then the manager's behavior is largely limited by the interest and loss for the position. Because the board of directors has the right to appoint executives, so ownership concentration and the size of the board of directors will also be the influence on the bank's risk bearing.

\subsection{Foreign Literature Review}

By reading the literature, the author found that for the bank's internal governance problems the overseas lies more in the analysis of the effect of individual factors on the risk bearing, and it is rare to study the bank risk bearing from the angle of the internal governance. So here, we understand the impact of individual factors on the bank first, and then make further study of all aspects of internal governance on its influence.

In the aspect of equity structure, assets risk and default risk of the bank will depend on the controlling shareholders [2], in the empirical study of 249 banks in Europe, they divided the banks into state-owned and private investment banks, and add the nature of the shareholders share respectively to the model in the study discussion, it is concluded that private investment banks prefer to high-risk investment, and state-owned does not have much impact. Angkinand and Wihlborg selected the eastern European and Asian Banks as the research object through empirical analysis, it is concluded that the state-owned Banks and large state-owned Banks tend to take more risk. Different study objects get the opposite conclusions, it means the equity nature indeed have large influence on bank's risk-taking. So on the study of bank which is affected by government deeply, scholars generally will take the nature of first big shareholders as one of the important influencing factors. And to a great ex- 
tent, ownership concentration illustrates the dispersion degree of shareholder rights, when ownership concentration is higher, the shareholders interests under the condition of highly consistent will drive the risky behavior, in order to get higher yields [3]. Saunders used data from 38 Banks in 1978-1985, studied the relationship between ownership structure and bank risk-taking, and made a conclusion that the higher the ownership concentration, banking risk is greater [4].

Board affects the bank risk-taking generally in two aspects, namely the board size and proportion of independent directors, some of which the study of the former is more abundant. Bank directors as a governing body, is more important than the others, because its assets trust responsibility is not only for shareholders, but also extends to depositors and regulators [5]. Shams used 212 holdings bank of 1997-2004 to construct the model, found that bank risk-taking and effective board is a positive relationship, and relationship with CEO power into reverse. In this case, the effective board means smaller size of the board of directors. For the more effective board, because of its highly consistent with shareholders will, so the purpose is to maximize shareholder rights and interests, then it must bear higher risk in order to satisfy shareholders' preferences [6]-[7]. Compared with managers, the independent director can make more reasonable decisions, this is because the independent directors must ensure that their reputation value [8].

Executive compensation incentive mechanism is now widespread, because executives decide the enterprise's daily production activities and to a large extent, the bank's risk bearing directly depends on the risk preference of executives, and CEO tenure and appointed will affect the CEO's risk preference. Shams concluded that CEO power had a reverse relationship with bank risk-taking through the empirical study [6]. If the CEO refute directors resolution with higher risk, then the bank will show lower risk appetite, because management prefer to avoid risk [9].

Based on these theories, Rich Fortin et al. used 83 large state-controlled Banks as the research objects, to investigate the influence that the owner structure, managers' pay, shareholder and management control of the distribution of corporate governance on bank risk-taking. Research shows that when banks do not have a high level of culture, foreign ownership owns more rights, the risk bearing level is higher, when executive compensation is higher, the lower the level of risk exposures [10]. Masaru Konishi and Yukihiro Yasuda took the banks of Japan as the research objects, mainly studies the board of director governance and ownership structure impact on bank's risk-taking. Through empirical analysis, they knew that the ownership structure had a nonlinear relationship with risk, when ownership concentration is higher and higher, the bank's risk exposure levels rise after falling first; The government's involvement would have a significant impact on bank’s risk [11].

\subsection{Domestic Literature Review}

Domestic research on banking internal governance issues is abundant, and most of them explore the influence of corporate governance on bank risk bearing from the overall, that provides a good theoretical basis for this paper. Equity structure was mainly studied from the first big shareholder stake or top shareholder's stake to study, some think that the higher the share of the first largest shareholder, the more wary of bank risk [12], While some others are considered it to be positively correlated relationship [13] [14]. Zhongxian Zhang used the data of eight listed Banks for studying and found out that the relationship of the proportion of the first big shareholder and the bank risk-taking was U nonlinear [15]. Board size effects on bank risk bearing is also debated, larger makes right more dispersed, and director can exercise more effective supervision of banks on the credit risk [14]. But at the same time, director role in supervision and management will be the corresponding drop, thus improve the bank's risk exposure levels. The role of independent directors in our country's corporate governance mechanism is not as big as we thought, its market positioning should have not only is the company's supervisor, but a decision maker. Yi Liu found the independent director was not only not constrained bank risk-taking, and are motivated to strengthen the risk to executive compensation incentive, also more comprehensive shows its and the relationship between the bank risk-taking. He found that, if the main way of salary incentive was cash, then it can effectively constrain with the bank's risk bearing level, but once the equity incentive involved, the interests of the executives will be influenced by return on equity, which tend to use high risk investment to get high profits, and improve the level of the bank's risk bearing [16].

\section{The Empirical Analysis}

\subsection{Data Source}

In order to the integrity of the sample, this article selects the total assets reached more than 50 billion of the city 
commercial bank until 2013 as sample, by reading 184 bank annual reports, selected the 23 city commercial Banks from 2008 to 2014 data. As there are seven bank executive compensation data missing, thus formed an unbalanced panel data. In addition, the regional GDP growth was gotten from China statistical yearbook.

\subsection{Variables and Assumptions}

\subsubsection{The Explained Variable}

Risk refers to the risk of commercial Banks, including in the risk business motivation, decision making and execution. Risk exposure level shows the size of the bank risk, and it is general replaced by alternative indicators of bank. In this article, as most city commercial banks are small and medium-sized, the information disclosure is very few, so we choose the risk-weighted assets accounted for the proportion of total assets to measure the risk level of Banks:

$$
\text { Risk }=\text { Risk }- \text { weighted assets } / \text { total assets }
$$

\subsubsection{Explanatory Variables}

\section{1) Ownership Concentration}

City commercial Banks in the system are not perfect in all directions, in terms of ownership concentration; we selected the two main variables, the nature of the largest shareholder and the first big shareholder control relative to the top ten shareholders.

a) Nature of the largest shareholder (FSN). If the first big shareholder is the local bureau of finance, the value is 1 , otherwise is 0 , which is aimed to examine the government role of city commercial Banks. Due to the government's decision are made from the overall regional economic development level, so if the government is the largest shareholder of a city commercial bank, it is likely to take bigger risk to invest projects which the income effect is small but social effect is large.

So we assume that: $\mathrm{H}_{0}$, if the value of FSN is 1 , there is a positive relationship with RISK.

b) The first big shareholder control relative to the top ten shareholders (FC). This article uses FC on behalf of the bank's equity concentration, this is mainly due to our country city business development besides Beijing, Ningbo and Nanjing listed so far, most are in growth period and concentrated in the hands of a small amount of shareholder equity. In theory, the shareholder pursue rights and interests maximization, so the target is to get high profits by operating investment on the condition of losing their all investment capital as limited liability, so the shareholders generally prefer to high-risk investments.

Thus we assume that: $\mathrm{H}_{1}$, the higher the ownership concentration, the higher the bank risk-taking.

\section{2) The Board of Director System}

The board of directors is the team that makes the final decision on the development, the scale of the board of directors and independent directors in the proportion of the board of directors will produce very big effect on the formation of a decision.

a) The board size (BS). In China, the board of directors system is not mature as the same as in the west and it exist the involvement of the government. The bank itself as a special organization that manage and control risk, have a lot of problem to choose between high yield and steady development in the process of continuous development. Foreign scholars had a dispute about it, some scholars believe that the board of directors with smaller size will increase the operational efficiency of the whole company, and is more advantageous to the company's operation and management, which can make more in the whole company interest development decisions. But other scholars believe that larger board of directors would make stumbles with the members, and it can effectively prevent some members of the more radical measures for the administration, more conducive to the healthy development of the company.

So we assume that: $\mathrm{H}_{2}$, the size of the board of directors have a passive relationship with bank's risk bearing, namely, the bigger the scale, the lower the level of risk exposures.

b) The independent directors proportion (IDP), or the independent directors in the proportion of the board size. The independent directors of a company are those have not other positions in the company, and independent on other main shareholders so they can make objective decisions. Thus, IDP would have an influence on the decision-making and implementation of the company. As independent directors have no relationship with the main shareholders, and they pay more attention to the bank's continuous development.

So we normally assume that: $\mathrm{H}_{3}$, the higher the IDP, the lower the bank's risk-taking. 


\section{3) Executive Compensation Incentive}

As the city commercial bank information disclosure is not complete, thus it's hard to obtain the data of executive incentive mechanism. So here, we use the mean of bank senior managers' compensation and executive shareholding to measure this indicator.

a) Executive compensation (EC). In the process of reading the annual report, if the annual report indicate the executive compensation, then take the average value directly, if only that the compensation of directors, supervisors and senior executives, then use this alternative. Because of executive compensation and corporate performance is bundled together, so executives generally tend to pursue high profits, but at the same time, because there is no clear provision in city business executives term, so the bank robustness development is also particularly important. In addition, after the financial crisis, executive compensation more attention to the bank's risk control because of the stiffer regulation. So, we assume that: $\mathrm{H}_{4}$, executive compensation incentive and the bank's risk bearing level has an inverse relationship.

b) CEO shareholding rate (CSR). Here we count the CSR to illustrate the impact that shareholding incentive mechanism on the bank's risk-taking. As the CSR is very low in city commercial banks, so we assume that: H5, executive shareholding relationship with the bank risk bearing level is not obvious.

At last, we select the local GDP as the control variable, year as the variable to control time. Because the bank's risk-taking is linear to the total assets, so we don't take it into consideration.

To sum up, all variables are summarized as follows: (Table 1 ).

\subsection{Model Specification}

According to the variables described above and the unbalanced panel data, we set two models as follows:

$$
\begin{aligned}
\text { LnRISK }= & \beta_{0}+\beta_{1} \mathrm{FSN}+\beta_{2} \mathrm{LnFC}+\beta_{3} \mathrm{BS}+\beta_{4} \mathrm{LnIDP}+\beta_{5} \mathrm{LnEC}+\beta_{6} \mathrm{LnCSR}+\beta_{7} \mathrm{GDP} \\
& \operatorname{LnRISK}=\beta_{0}+\beta_{1} \mathrm{FSN}+\beta_{2} \mathrm{LnFC}+\beta_{3} \mathrm{BS}+\beta_{4} \mathrm{LnIDP}+\beta_{7} \mathrm{GDP}
\end{aligned}
$$

When setting the model, because the level of risk exposures, equity concentration, the independent directors proportion and executive ownership are all percentage, and as the data between executive compensation and interpreted variable is far, which is not conducive to analysis, so we take their logarithm, to illustrate the relationship between them by investigating the relative changes in these variables.

Since we are using the unbalanced panel data, and generally there are fixed effects model, hybrid least squares and the random effects model to choose. So here, we should use Hausman test for it, and we come to the conclusion that the panel data is more suitable for random effects.

\subsection{Empirical Analysis}

\subsubsection{Descriptive Statistical Analysis}

In order to understand the variables, we use the descriptive statistics of Stata.

\begin{tabular}{|c|c|c|}
\hline Type & Variables & Instruction \\
\hline \multirow[t]{3}{*}{ Explained variable } & Risk-Taking & $\begin{array}{l}\text { RISK, risk-weighted assets accounted for the proportion of total } \\
\text { assets, \% }\end{array}$ \\
\hline & Nature of the Largest Shareholder & FSN, if it is the local bureau of finance, the value is 1 \\
\hline & Shareholding Concentration & $\begin{array}{l}\text { FC, the first big shareholder control relative to the top ten } \\
\text { shareholders, \% }\end{array}$ \\
\hline \multirow{4}{*}{ Explanatory variable } & Board Size & BS, the number of the board of directors \\
\hline & Independent Directors Proportion & $\begin{array}{l}\text { IDP, the independent directors in the proportion of the board of } \\
\text { directors, \% }\end{array}$ \\
\hline & Executive Compensation & EC, the mean compensation of the executives \\
\hline & CEO Shareholding Rate & CSR, CEO share-holding in the proportion of the total shares, \% \\
\hline Control variable & The local GDP & GDP, \% \\
\hline
\end{tabular}

Table 1. Variable summary.

Note: \%, \% are the units of the corresponding value. 
Seen from the chart, the standard deviation of the scale of the board of directors and senior executive shareholding ratio are large, more than $200 \%$ of the average, and the data is scattered, so as the model may not be very significant. The mean of executives shareholding logarithmic less than zero, it suggests that executives shareholding proportion is very small (In the source data, the value of executives shareholding is thousands), There is less influence on the explained variable. Moreover, we make a histogram with the mean value of risk bearing level (figure to omit), found that the variable showed a trend of decline in 2008-2011, and then began to rebound in 2012 and make a sharp increase in 2013. So here, we divided the year to make a statistics: (Table 2).

From the table we can see, according to the division of the level of risk-taking change, the average of LnIDP and LnEC have relatively similar changes, while the rest of the several variables decline, in particularly, the LnCSR change from positive to negative, it fully illustrates that the bank market share has greatly increased on the basis of the remain unchanged executive share holdings. Such changes can explain the correlation between the explanatory variables and explained variable to some extent, but not accurate, so we need to illustrate the relationship between the variables through the model of regression (Table 3).

If we only observe the change of the average of variables, we can see, to FSN, it declines in the last two years, that means the value of FSN for city commercial banks are prefer to be 0 , thus we can make a conclusion that with the development of city commercial banks, they are getting out of control of the local bureau of finance and become the joint equity banks. The change of BS and IDP illustrate that the size of board of directors is becoming small and the proportion of independent director is increasing. Obviously, these changes are all made for the banks to adapt the new market.

\subsubsection{Correlation Analysis}

Due to the variable selection has certain relevance, so we carried out the correlation analysis on the explanatory variables.

Table 2. Descriptive statistical analysis.

\begin{tabular}{cccccc}
\hline Variable & Observations & Mean & Standard Deviation & Min & Max \\
\hline LnRISK & 131 & 4.04478 & 0.1459 & 3.6376 & 4.3567 \\
FSN & 131 & 0.3206 & 0.4685 & 0.0000 & 1.0000 \\
LnFC & 131 & 3.2151 & 0.4225 & 2.3979 & 4.3567 \\
BS & 131 & 13.1527 & 3.2260 & 4.0000 & 19.0000 \\
LnIDP & 120 & 3.2509 & 0.4583 & 2.0794 & 3.8067 \\
LnEC & 92 & 4.5182 & 0.5402 & 3.3499 & 5.7988 \\
LnCSR & 69 & -0.2371 & 2.0977 & -4.6052 & 4.4439 \\
GDP & 131 & 10.4581 & 1.9345 & 8.0000 & 15.0000
\end{tabular}

Table 3. Descriptive statistical analysis of variables in two periods.

\begin{tabular}{|c|c|c|c|c|c|c|c|c|c|}
\hline Year & \multicolumn{3}{|c|}{ 2008-2014 } & \multicolumn{3}{|c|}{ 2008-2011 } & \multicolumn{3}{|c|}{ 2012-2014 } \\
\hline Variable & Observation & Mean & $\begin{array}{l}\text { Standard } \\
\text { Deviation }\end{array}$ & Observation & Mean & $\begin{array}{c}\text { Standard } \\
\text { Deviation }\end{array}$ & Observation & Mean & $\begin{array}{l}\text { Standard } \\
\text { Deviation }\end{array}$ \\
\hline LnRISK & 131 & 4.04478 & 0.1459 & 78 & 4.0137 & 0.1372 & 53 & 4.0904 & 0.1477 \\
\hline FSN & 131 & 0.3206 & 0.4685 & 78 & 0.3396 & 0.4645 & 53 & 0.3077 & 0.4781 \\
\hline LnFC & 131 & 3.2151 & 0.4225 & 78 & 3.2349 & 0.4002 & 53 & 3.1859 & 0.4558 \\
\hline BS & 131 & 13.1527 & 3.2260 & 78 & 13.2180 & 3.2976 & 53 & 13.0566 & 3.1465 \\
\hline LnIDP & 120 & 3.2509 & 0.4583 & 71 & 3.1912 & 0.4731 & 49 & 3.3373 & 0.4258 \\
\hline LnEC & 92 & 4.5182 & 0.5402 & 39 & 4.4189 & 0.5987 & 53 & 4.5792 & 0.4966 \\
\hline LnCSR & 69 & -0.2371 & 2.0977 & 25 & 0.2355 & 2.2440 & 44 & -0.5057 & 1.9861 \\
\hline GDP & 131 & 10.4581 & 1.9345 & 78 & 11.2051 & 1.8259 & 53 & 9.3585 & 1.5329 \\
\hline
\end{tabular}


From the table above, the correlation absolute values of variables do not surpass 0.5 , thus we can make a conclusion that they do not exist correlation, as a result, we don't need to process explanatory variables (Table 4).

\subsubsection{Empirical Results}

Because the data which we choose is panel data, so there may be common problems of cross section data and time series at the same time, here, we should do some relevant inspection to increase the model fitting effect. Through the heteroscedasticity testing, it is concluded that the value of $\mathrm{P}$ is 0 , refusing to the assumption homoscedasticity, thus we know the heteroscedasticity of the model is serious.

So we adopt the GLS to eliminate heteroscedasticity. Through the GLS estimation, we draw an empirical regression results as follows.

From the regression coefficient of explanation variable we can see, the nature of the first shareholder and executives hare holding do not have particularly significant relationship with RISK; Only the independent directors proportion relation with risk exposure level were positively correlated, namely, the more the independent directors, the greater the risk bearing level. Other explanatory variables are in the opposite direction, the bigger the LnFC, BS, the better the executive compensation incentive mechanism, the lower the level of risk exposures (Table 5).

Here, we can see that some conclusions made by regression model have some discrepancy with the hypothesis that we mentioned, because the assumption is based on the empirical conclusion as previous, which is based on the data of listed Banks and enterprises, while the city commercial bank is different.

\subsubsection{Conclusions of Empirical Analysis}

On the basis of the regression results above, we will briefly describe the relationship between explanatory variables and explained variable below (Table 6).

Therefore, we state the conclusion from the three aspects of internal governance.

\begin{tabular}{|c|c|c|c|c|c|c|c|}
\hline & FSN & LnFC & BS & LnIDP & LnEC & LnCSR & GDP \\
\hline FSN & 1.0000 & & & & & & \\
\hline LnFC & -0.051 & 1.0000 & & & & & \\
\hline BS & -0.2748 & -0.3712 & 1.0000 & & & & \\
\hline LnIDP & -0.3435 & -0.0058 & 0.2589 & 1.0000 & & & \\
\hline LnEC & -0.077 & -0.0601 & 0.2717 & 0.3006 & 1.0000 & & \\
\hline LnCSR & 0.1597 & -0.4327 & -0.0152 & -0.0636 & 0.0359 & 1.0000 & \\
\hline GDP & -0.1785 & 0.2204 & -0.0999 & -0.1542 & -0.1597 & -0.2470 & 1.0000 \\
\hline
\end{tabular}

Table 5. Regression results.

\begin{tabular}{ccc}
\hline & Model $(1)$ & Model $(2)$ \\
\hline FSN & 0.0142 & $0.0307^{*}$ \\
& $(-0.0197)$ & $(0.0161)$ \\
LnFC & $-0.2328^{* * *}$ & $-0.1411^{* * *}$ \\
BS & $(0.0287)$ & $(0.0240)$ \\
& $-0.0104^{* * *}$ & 0.0007 \\
LnIDP & $(-0.0104)$ & $(0.0028)$ \\
LnEC & $0.065^{* *}$ & 0.0235 \\
& $(0.0264)$ & $(0.0199)$ \\
LnCSR & $-0.0573^{* * *}$ & - \\
GDP & $(0.0204)$ & - \\
Wald Chi(2) & -0.0032 & $-0.0284^{* * *}$ \\
P Value & $(-0.0045)$ & $(0.041)$ \\
& $-0.0186^{* * *}$ & 141.85 \\
\hline
\end{tabular}

Note: ${ }^{* * *},{ }^{* *},{ }^{*}$, illustrate that $\mathrm{P}$ values on the significant level of $1 \%, 5 \%, 10 \%$ is significant; The standard deviation of variables are shown in brackets. 
Table 6. Conclusion.

\begin{tabular}{cc}
\hline Explanatory Variables & The Relationship with Explained Variable \\
\hline FSN & non-significant \\
LnFC & Negative correlation \\
BS & Negative correlation \\
LnIDP & Positive correlation \\
LnEC & Negative correlation \\
LnCSR & Non-significant \\
GDP & Negative correlation \\
\hline
\end{tabular}

1) The FSN has not significantly affected on the RISK, but FC has an opposite relationship with RISK. This conclusion is different from the assumption before, it is because of the change of the market. City business gradually gets out of control of government in the period of restructuring and becomes the joint equity bank, so the influence of the nature of the largest shareholder is weak. The relationship between FC and RISK is opposite, namely the higher the concentration, the lower the level of the risk-taking, and fortunately, we find it was consistent with the conclusion which has been made by some former scholars that the relationship between concentration and RISK is non-linear, the relational graph is like a U. In the early period of development, city commercial banks unfortunately come across the financial crisis and the competition of the market is becoming more and fiercer, as the level of risk-taking will become low when the ownership concentration become higher, that means the ownership concentration has constraint function of risk-taking.

2) The bigger the board, the lower the level of risk-taking. As we know, the bigger the board, the lower the efficiency of management. When we make decisions on the project, as the benefits and risks coexist, different interest groups are very hard go down to share risks in the case of failed to get the same benefits, so finally it will reached a resolution which prefers to low level of risk, thus lowers the bank's risk-taking level. And we have known from the literature that the effect which independent directors act on the city commercial banks is limited, and in some aspect, they have the motivation to increase the risk (Yi Zhang, 2010). When the proportion of independent directors is high, the scale of the directors which play the decisive role is small, then the risktaking is high.

3) As to the executive compensation, it is opposite with the relationship of bank's risk-taking, conforming to the assumption. That is because, besides of the Beijing, Ningbo, Nanjing, other city commercial banks are all the non-listed banks, so the executive compensation incentive is largely related to its performance only. In addition, in these 23 research objects, there is only one bank exists executives tenure system, so the impact on the executives disappears, and on this condition of regulatory system and market environment, executives will pay more attention to the risk management for banks. However, the CSR is truly small, and account for only a small part of profit distribution in the shareholder, so it would not affect the bank's risk-taking a lot.

In addition, in order to test the model's stability, we analyze the data by using maximum likelihood estimation, and get the $\mathrm{P}$ value of the model is 0 , the explanatory variables LnFC, BS, LnIDP, LnEC and GDP is consistent with the results of GLS regression, it illustrates that the model is stable.

\section{Conclusions and Recommendations}

This article takes the city commercial banks whose asset is more than 50 billion by the end of 2013 as the research objects, and we have studied the internal governance influence on bank's risk-taking. At first, we set many assumptions on the basis of the study of the predecessors, and then through the empirical analysis, we have come to a conclusion. The conclusion is different from the assumptions in some aspects, and it exactly shows the difference of our city commercial banks relative to other large commercial banks, and fortunately the conclusion is consistent with the study of predecessors. Thus, according to the conclusion, we come up with some suggestions for the development of the city commercial banks.

1) If the ownership concentration of city commercial banks is higher, level of risk-taking is lower. To this conclusion, combined with the research of nonlinear relationship, we think that there may be a certain time limit, 
when the city commercial banks develop to a certain level, the ownership concentration peak, the conclusion may no longer apply. But when we aim at the present stage, we think that the city commercial banks can increase the equity concentration, the main reason is that equity concentration not only has a positive effect on bank risk-taking, but also has a positive impact on bank performance as the target of the shareholders is the maximize equity.

2) As for the size of the board of directors, though the bank are generally stay in the growth stage, we can find from the data that the size is about 15 or so, the biggest may be 19 people around, so we advise that the board of director can appropriately expand the scale, thus it can reduce the risk of the bank, which has promoting effects on the development of city commercial banks at the beginning of the growth. For the independent directors, the proportion of independent directors in city commercial banks is not very high, so we mainly suggest rectifying the role of the independent director in the bank's internal governance. Because the bank itself is a risk of the enterprises, independent and objective judgment is an essential part of a bank. To some extent, independent directors now are in the nature of a front position and do not play its proper role, so if independent directors play its true role of internal governance in the bank, it will be really good for the sustainable development of city commercial Banks.

In city commercial banks in China, only very few banks exist executive tenure system, so the executive compensation incentive system will largely affect bank management and risk decision-making, but as city commercial banks are most still in the early stage of development, the system is not very well. In this paper, we found that executive compensation incentive mechanism for the bank's risk bearing had positive effect, but in the previous studies there were also some conclusions that executive power would be opposite with the banks' risk-taking. So here, we recommend that the city commercial banks would continue to improve the executive compensation incentive mechanism, and the board should appropriately relax executives, so that they could give full play to the executive ability. On the other hand, the executive experience also can't be talked. Many city business executives are moved from large commercial banks, and sometimes they would be easy to judge the target resolution for the banks with the past experience, and city commercial banks in many aspects, such as assets, production equipment, access to business are difficult to compare with the large commercial banks, so we hope that the executives pay more attention to enterprise management practically.

\section{References}

[1] Lu, M.F. (2015) About the Development Strategy of City Commercial Banks to Cope with the "Newnormal”. Economic Review, 30-33.

[2] Barry, T.A., Lepetit, L. and Tarazi, A. (2011) Ownership Structure and Risk in Publicly Held and Privately Owned Banks. Journal of Banking \& Finance, 35, 1327-1340. http://dx.doi.org/10.1016/j.jbankfin.2010.10.004

[3] Angkinand, A. and Wihlborg, C. (2010) Deposit Insurance Coverage, Ownership, and Bank’s Risk-Taking in Emerging Markets. Journal of International Money and Finance, 29, 252-274. http://dx.doi.org/10.1016/j.jimonfin.2009.08.001

[4] Saunders, A., Stock, E. and Nickolaos, G. (1990) Ownership Structure, Deregulation, and Bank Risk Taking. The Journal of Finance, 45, 643-654. http://dx.doi.org/10.1111/j.1540-6261.1990.tb03709.x

[5] Macey, J.R. and O’Hara, M. (2003) The Corporate Governance of Banks. Economic Policy Review, 91-107.

[6] Pathan, S. (2009) Strong Boards, CEO Power and Bank Risk-Taking. Journal of Banking \& Finance, 33, $1340-1350$. http://dx.doi.org/10.1016/j.jbankfin.2009.02.001

[7] Galai, D. and Masulis, R.W. (1976) The Option Pricing Model and the Risk Factor of Stock. Journal of Financial Economics, 3, 53-81. http://dx.doi.org/10.1016/0304-405X(76)90020-9

[8] Fama, E.F. and Jensen, M.C. (1983) Separation of Ownership and Control. Journal of Law and Economics, 26, 301325. http://dx.doi.org/10.1086/467037

[9] Smith, C.W. and Stulz, R.M. (1985) The Determinants of Firms' Hedging Policies. The Journal of Financial and Quantitative Analysis, 20, 391-405. http://dx.doi.org/10.2307/2330757

[10] Fortin, R., Goldberg, G.M. and Roth, G. (2010) Bank Bisk Taking at the Onset of the Current Banking Crisis. Financial Review, 45, 891-913. http://dx.doi.org/10.1111/j.1540-6288.2010.00277.x

[11] Konishi, M. and Yasuda, Y. (2004) Factors Affecting Banks Risk Taking: Evidence from Japan. Journal of Banking \& Finance, 28, 215-232. http://dx.doi.org/10.1016/S0378-4266(02)00405-3

[12] Chen, Y.L. (2013) Study of Corporate Governance of City Commercial Banks’ Risk-Taking and the Influence of Operating Performance. Southwestern University of Finance and Economics, Chengdu. 
[13] Wang, P.C. (2012) The Company Internal Governance Research on the Influence of Our City Commercial Bank Risk-Taking. Southwestern University of Finance and Economics, Chengdu.

[14] Kong, D.L. and Dong, J. (2008) The Empirical Analysis the Impact of Corporate Governance Mechanism on Commercial Bank Risk Bearing. Journal of Central University of Finance and Economics, 39-42.

[15] Zhang, X.Z. (2010) The Influence of Corporate Governance on Our City Commercial Bank Risk-Taking Behavior of Empirical Research. Suzhou University, Suzhou.

[16] Liu, Y. (2010) Commercial Bank Risk-Taking Behavior Research-Based on Corporate Governance Perspective. Southwestern University of Finance and Economics, Chengdu. 